\title{
ČLÁNKY
}

\section{The Future of the EU: Rhetoric in Service of the Commission's Agenda?}

\author{
Nellie Munin*, Marielle Matthee**
}

\begin{abstract}
This article examines whether the White Paper on the Future of Europe the EU Commission published in March 2017, encourages real public discourse on different options for the future of Europe. In other words, are the different options of the White Paper ground for discussion in which 'every voice will be heard' as promised, or are there implicit restrictions to the inclusiveness incorporated in its approach?

Analyzing this document using theories on rhetoric and rhetoric techniques, it suggests that the White Paper uses rhetoric devices to create a misleading impression of inclusiveness, while in fact aiming at the same target as the Five Presidents Report of 2015: advocating for the highest degrees of integration.
\end{abstract}

\section{Keywords}

The EU; the Five Presidents Report; the White Paper; Rhetoric; Enhanced Integration.

\section{Introduction}

In a report published in June 2015, titled Completing Europe's Economic and Monetary Union, known as the 'Five Presidents Report', 'the five presidents of the major EU institutions, led by the EU Commission, suggested that the best way to pull the European Union out of the severe financial crisis, with which it has struggled since 2010, and to immune its economy from future crises is to turn the EU, by 2025, into a full financial, fiscal, monetary and economic union, hopefully followed by a political union. Focusing on this option only, the report specified the ways to achieve it.

* Nellie Munin, LLD, Adv., independent researcher and lecturer. Former associate professor, the law school, Zefat Academic College, Israel. Former Minister of Economic Affairs in the Israeli Mission to the EU. Former Chief Legal Advisor, the state revenue administration, the Israeli Ministry of Finance. / E-mail: gmun@netvision.net.il

** Marielle Matthee, PhD, International Law and International Organizations, BA in English Language and Culture, guest lecturer at Leiden University, teacher in Academic Writing, conducts research in the field of Law and Literature. Former Researcher in international and European law at the T.M.C. Asser Institute in The Hague. Former legislative advisor in the former Dutch Ministry of Agriculture, Nature and Food Quality. / E-mail: marielle.matthee@orange.fr

1 JUNCKER, Jean Claude. Completing Europe's Economic and Monetary Union [online], 2015. Available at: http://ec.europa.eu/priorities/economic-monetary-union/docs/5-presidents-report_en.pdf 
This determinant vision was highly criticized, both in terms of the decision making process, i.e. for being imposed without sufficient public discourse, and in terms of its message, as most EU member states and citizens were not ready to tighten up European integration as suggested. ${ }^{2}$

Since then, the political crisis in the EU has only deepened, due to the refugees' crisis that burst in 2015-16 and the Brexit. The confrontation between the EU and some EU members over the hosting of refugees peaked with Hungary's and Slovakia's actions against the provisional mechanism for the mandatory relocation of asylum seekers and the resulting EU dismissal thereof. ${ }^{3}$ Likewise, the decision of the UK to withdraw from the EU signalized the decision makers that one-sided insistence on deepening integration might not be a politically wise step at that stage.

The refugee crisis and the Brexit reinforced the importance of reaching out for EU member states' and citizens' support for any further advancement. The White Paper on the Future of Europe: Reflections and Scenarios for the EU27 by 2025 (hereafter: The White Paper) published in March $2017^{4}$ seems to reflect this understanding. Presenting five optional scenarios, ranging from status quo to the initiation of the Five Presidents Report's vision, this document calls for a broad public discourse on the future of the EU as seen by its citizens, that should boil down to pragmatic conclusions regarding a chosen formula on the EU's way forward before the next elections to EU Parliament, in 2019.

However, a closer view at the White Paper reveals that such a conclusion may be too hasty. The paper contains many rhetorical patterns expressing it highly political nature. Rhetoric is not a surprising tool for the EU to apply in the context of an increasing mistrust in its institutions. According to Charteris-Black, ${ }^{5}$ rhetoric is a logical tool to install trust in a society in which leaders (and the programs of the institutions they represent) depend increasingly on elections and on the impression they leave on the voters. In line with Charteris-Black, this article recognizes politicians and institutions' need to persuade, believing that strong and hopeful programs contribute to trust. ${ }^{6}$ However, it also

2 E.g. MUNIN, Nellie. The 'Five Presidents Report': Dogs Bark but the Caravan Moves on? The Journal of European Politics and the Society, 2016, Vol. 17, no. 3, pp. 401-420.

3 European Court of Justice. Judgment in Joined Cases C-643/15 and C-647/15 Slovakia and Hungary v. Council [online]. 2017. Available at: http://curia.europa.eu/juris/documents.jsf?num=C-643/15

4 JUNCKER, Jean Claude. The White Paper on the Future of Europe: Reflections and Scenarios for the EU27 by 2025 [online]. 2017. Available at https://ec.europa.eu/commission/sites/beta-political/files/ white_paper_on_the_future_of_europe_en.pdf

5 CHARTERIS-BLACK, Jonathan. Politicians and Rhetoric. The Persuasive Power of Metaphor. 2nd ed. London: Palgrave Macmillan, 2011, p. 1.

6 See for further reading on the contemporary importance of rhetoric to convey political messages in CROWE, Nicholas and David FRANK (eds.). Rhetoric in the 21st Century: an Interactive Oxford Symposium. Cambridge: Cambridge Scholar Publishing, 2016, p. 5; BERLIN, James. Revisionary Histories of Rhetoric: Politics, Power and Plurality. In: VITANZA, Victor (ed.). Writing Histories of Rhetoric. Southern Illinois University Press, 2013, pp. 112-127. 
considers the public's need to recognize distorted information, belief-systems underlying the presentations, and misrepresentation of facts and concepts, in order to define where its hopes will be best placed. ${ }^{7}$ Therefore, this article examines several rhetorical tools the White Paper uses, to define whether and to what extent it marks a real approach change compared to the Five Presidents Report approach, or whether it uses rhetoric devices to create this impression, while in essence not abandoning its approach. The first part of this article considers some general rhetorical tools, such as the style of language, the use of words and their frequency, and visual impressions inserted in the White Paper. The second part examines the use of artistic proof, such as ethos, pathos and logos, to obtain a better understanding of the White Paper's author, its narrative and its attitude. The last part addresses the different scenarios as set out in the White Paper, defining the Commission's preference for one of these scenarios, based on the insights on its use of rhetoric.

\section{Section 1: General approach}

\section{Simple language}

The White Paper uses a commonly understandable language in all its parts, deliberately refraining from using professional language. ${ }^{8}$ The language of the White Paper is a language that is directly addressing its readers in what seems at first glance an inclusive manner. It even avoids using literal allegories such as the comparison of the EU to a common house, sheltering its inhabitants from storms, now in need for repair, used in the Five Presidents Report. ${ }^{9}$ The use of a less technical language can be considered a reaction to the criticism on the Five Presidents Report's language, that seemed to reflect an ambivalent approach in terms of reaching out to the public, swinging between an apologetic and populist language aimed at common EU citizens in its beginning and end, and a very technical language, understood mainly by professionals, in between. ${ }^{10}$

To convey a clear, straightforward, and simple message the relatively long text reflects amplification - repetition of words. ${ }^{11}$ Thus, for example, 'crisis' appears 7 times in the text, 'values' - 8 times, 'expectations' - 9 times, 'peace' - 10 times, 'challenge' and 'vision' - 13 times each, 'collective(ly) - 14 times, 'united' - 14 times, 'future' - 26 times, 'security' - 28 times. These words are similar in the sense that they all resonate the willingness to construct a Europe that is a community, characterized by inclusiveness. Their repetition provides a positive tone to people having doubts.

7 CHARTERIS-BLACK, op. cit., n. 5, p. 2.

8 JUNCKER, op. cit., n. 4, p. 15.

9 JUNCKER, op. cit., n. 1, p. 5, para. 4.

10 MUNIN, op. cit., n. 2.

11 YOURDICTIONARY. Examples of Rhetorical Devices [online]. 2017. Available at: http://examples.yourdictionary.com/examples-of-rhetorical-devices.html 


\section{Positive approach}

In general, the White Paper is characterized by a very positive and constructive rhetoric. Another rhetoric technique reinforcing this spirit is antanagoge ${ }^{12}$ - placing a criticism and compliment together to lessen the former's impact by the latter. Thus, for example, the detailed description of the crossroad the EU faces now (implying criticism regarding the reasons that brought the $\mathrm{EU}$ to this position), is followed by a compliment to lessen this effect, reiterating: "Europe has always been at a crossroads and has always adapted and evolved."13

\section{Illustrative measures supporting the literal message}

In line with the use of simple language, the White Paper sums up the features and implications of each scenario by a table raw, to the readers' convenience. At the end of the paper, all table raws are assembled, to create a comparative table of all options. Likewise, the White Paper uses a lot of graphics: inspiring pictures, charts etc. to illustrate its messages beyond words, mainly in its introductory part. ${ }^{14}$

Particularly interesting is the design on the opening page of the White Paper as it hides another dimension that runs to a certain extent counter to its appearance. Like the opening page of the Five Presidents Report, the opening page of the White Paper uses a graphic allegory. It is interesting to compare the graphics of these two documents as the White Paper follows a similar allegorical approach, but uses a more layered approach, a simpler image hiding a more implicit and complex message. The opening page of the Five Presidents Report includes an image of the EU's map, on which figures of men, women and children are positioned at random without any indication that they belong to a certain particular national or ethnic group (uniformity without diversity). Furthermore, it includes a house and bridges connecting territories and as a graphic allegory it illustrates the literal message of the Report: the EU is a home for all its citizens, who share the same destiny irrespective of their gender, age, ethnic, cultural, or national identity, bridging between nations. At first glance, the image reflects openness, inclusiveness and freedom, sending out the message that it is important to make the EU work. Yet, a closer look at the figures appearing on the EU geographical map reveals that they are two-dimensional stereotype men, women and children. Furthermore, the house giving comfort and the bridges allowing access are drawings that resemble the images on Euro money paper. This turns the EU zone into a confinement of uniformity, holding on to images used in the monetary policy and lacking the three-dimensional reality of diversity.

In contrast, the first page of the White Paper is decorated with a simpler image of eight flying paper birds. There is no background, in contrast to the image of the Five Presidents

\footnotetext{
12 YOURDICTIONARY, op. cit., n. 11.

13 JUNCKER, op. cit., n. 4, p. 6.

14 Ibid., pp. 6-11.
} 
Report, but the birds' alignment suggests that they follow each other as a flock. This image can be interpreted as a message of peace (if the birds are interpreted to be doves, or alternatively - if they are interpreted to be origami cranes, commonly supporting the prayers for peace in the temples of Hiroshima, Japan). As paper birds, they may be associated with a string of a so-called Senbazuru (thousand origami cranes) traditionally made in the far East as a wish for a prosperous and long marriage. The image on the frontpage is reinforced by the use of the expression "renew our vows", ${ }^{15}$ usually associated with long, satisfactory marriages. Thus, they may symbolize the unity and inter-dependence of EU members, compared to a flock of birds, and the freedom of decision, generally associated with birds. However, at the same time this image has a more negative connotation of bird flocks sticking together to survive, and follow the same direction every year, despite the illusion of freedom they may symbolize. Furthermore, despite some small differences in size, head and tail, the birds resemble each other strongly, suggesting a high degree of uniformity that further European integration would require. This sense of confinement is equally reflected in the fact that the birds are paper birds, signaling the continuation of the highly criticized bureaucratic side of the EU as a legal, artificial entity created by paperwork. Likewise, the drawing represents the art of origami: a threedimensional art is expressed in an oppressing two-dimensional manner.

\section{Avoiding details}

The White Paper suggests five scenarios, explicitly stressing that they form only sketches and that a detailed plan will be worked out at a later stage, subject to the chosen scenario. Each scenario is depicted in very general terms, including a few examples (called 'snapshots') for the implications that its choice may have, rather than a deep and detailed analysis of its consequences. This approach is justified on grounds of simplicity, to allow broad accessibility, following the criticism on the Five Presidents Report that was too detailed to follow by common, unprofessional readers.

It is further justified on grounds of flexibility:

"The five scenarios are illustrative in nature to provoke thinking. They are not detailed blueprints or policy prescriptions. Likewise, they deliberately make no mention of legal or institutional processes - the form will follow the function... The final outcome will undoubtedly look different to the way the scenarios are presented here."16

However, for the sake of simplicity of the message and flexibility of options, the Paper lacks the inevitable detailing necessary to enable serious discussion before choosing the desired way forward. Thus, it effectively undermines such discourse. While Aristotle thought that speaking simply to large audiences is an advantage uneducated men

\footnotetext{
15 JUNCKER, op. cit., n. 4, p. 26.

16 Ibid., p. 15.
} 
(or leaders), speaking from their experience, have over educated men laying down "broad general principles", ${ }^{17}$ a research analyzing Presidential messages in the United States establishes that increase in rhetorical simplicity (or even 'anti-intellectual' rhetoric) effectively prevents real discourse, and predicts an increase in the number of executive orders offered by the president, i.e. unilateral action. ${ }^{18}$

\section{Section 2: Reasoning}

With the legitimacy of the European Union at risk and its future uncertain, the Commission can use rhetoric to restore the lack of confidence to a certain extent, and position itself as a reliable caretaker of the concerns of EU citizens.

Aristotle in his Art of Rhetoric ${ }^{19}$ distinguishes several instruments of rhetoric that may facilitate the delivery of such a political message, amongst which are the 'artistic proofs' ethos, pathos and logos. In this section, these artistic proofs are used as a tool for close-reading the White Paper and discovering the underlying message of Juncker and the Commission.

\section{Ethos: Building Trust}

Aristotle describes ethos as the instrument of persuasion that relies on the character of the speaker to establish a relationship of trust with the audience. The authors of the White Paper position themselves as caretakers, peacebuilders, relying on shared values of peace and solidarity. ${ }^{20}$ They describe how these values form the basis of the European Union's construction, using them to create a relationship of trust with their audience. They base their authority to address the audience today on the momentum of the EU's $60^{\text {th }}$ anniversary.

\section{Using the Momentum}

According to Verduijn, "crises and focusing events are one of the most successful opportunities for advancing policy ideas." ${ }^{21}$ While the Five Presidents Report took advantage of the financial crisis to advocate enhancement of European integration, the White Paper takes advantage of a positive event: the EU's $60^{\text {th }}$ anniversary. ${ }^{22}$ Suggesting that

17 ARISTOTLE. The Art of Rhetoric. Translation and index by W. Rhys Roberts [online]. Megaphone eBooks, 2008, p. 145. Available at: http://www.wendelberger.com/downloads/Aristotle_Rhetoric.pdf

18 OLDS, Christopher. Assessing the Relationship between Presidential Rhetorical Simplicity and Unilateral Action. Politics and Governance, Vol. 3, no. 2, 2015, pp. 90-98 [online]. DOI: https://doi.org/10.17645/pag. v3i2.303. Available at: https://www.cogitatiopress.com/politicsandgovernance/article/view/303/303

19 ARISTOTLE, op. cit., n. 17.

20 See reference to SCHUMAN In: JUNCKER, op. cit., n. 4, p. 4.

21 VERDUIJN, Simon. Framing Strategies and Connective Capacity in Water Governance Policy: the Case of the Second Delta Committee. In: EDELENBOS, Jurian, Nanny BRESSERS and Peter SCHOLTEN (eds.). Water Governance as Connective Capacity. London \& New York: Routledge, 2016, pp. 211-228.

22 JUNCKER, op. cit., n. 4, pp. 3, 6. 
this is a good point in time for introspection, taking account of EU's achievements and the issues that still necessitate improvement, it calls to "rediscover our pride and shape our own future". ${ }^{23}$ Without directly identifying itself as such, the prospect of 27 Member States 'standing united in peace and friendship', unthinkable 60 years ago, turn the day-today branch of the European Union into a peacebuilder, a mediator bringing friendship. The White Paper reminds the reader of the European Union's founding fathers story, which illustrates that clear vision is nothing new. Furthermore, the remembrance of "those before us whose dream for Europe has become reality", ${ }^{24}$ suggests that this strong capacity of turning dreams into reality still exists. Trust is thus advocated on grounds of shared destiny and effort that has led to impressive achievements till now.

\section{Relying on past experience and Praising achievements}

The White Paper starts from the very beginning, going back to the roots of the European narrative. After referring to the history and legacy of the EU, it mentions the EU's achievements since its establishment, such as the immense growth in EU's size in recent years, turning it into the world's largest single market, trade power and development and humanitarian aid donor, the Euro - the second most used global currency, the political strength and bargaining power of this alliance in the international arena, playing a leading role in initiating the 'historic deal' with Iran on its nuclear program, the Paris Climate Agreement, the adoption by the UN of the Sustainable Development Goals for 2030, the obtainment of the longest peace period since 1500, and the initiation of the world's biggest multinational research program - Horizon $2020 .^{25}$

Besides taking pride in its past experience, the Commission equally shows that its caretaker role is extended to a global level. The reference to humanitarian and global security contribution builds on the rhetoric of 'the responsibility to protect', associated with global powers. ${ }^{26}$

Ensuring its readers, it recalls that throughout EU's history it overcame challenges and controversies, including the European Defense Community of the 1950's, the exchange rate shocks of the 1970's and rejections in referenda in recent decades. ${ }^{27}$

The Five Presidents Report transferred a similar message, only there it was more focused on the history of the common currency and the economic importance of the EU in the global arena rather than on the general EU history. ${ }^{28}$

23 JUNCKER, op. cit., n. 4, p. 26.

24 Ibid., p. 3.

25 Ibid., pp. 6-8.

26 Read more on the political rhetoric of global 'responsibility to protect' in HEHIR, Aidan. The Responsibility to Protect: Rhetoric, Reality and the Future of Humanitarian Intervention. New York: Plgrave McMillan, 2012.

27 JUNCKER, op. cit., n. 4, p. 6.

28 JUNCKER, op. cit., n. 1, pp. 4, 17. 
The past experiences cited in the White Paper and the Commission's record of overcoming crises in different fields justify the image of the Commission as caretaker capable to affront the current complex challenges, implying it may be trusted.

\section{Pathos: Invoking Emotions}

Does this strong image of the European Union, which relies on the force of solidarity to succeed, suffice to persuade the audience to feel part of it? The White Paper expresses a strong sense of community and belonging in various ways, such as the frequent use of the first person plural pronoun 'we', the emphasis on a common history, ${ }^{29}$ and willingness to face common challenges and threats. Pathos, another artistic proof in Aristotle's art of rhetoric, relies on emotion as an element that influences reasoning. According to Gross, "emotions are the contours of a dynamic social field manifest in what's imagined and forgotten, what's praised and blamed, what's sanctioned and silenced." 30 This technique seems to be particularly effective in the political context discussed since, according to Gross, human emotions are conditioned by power relations and social hierarchies.

The rhetoric of the White Paper builds upon certain emotions to convince. This section analyses the coherence of using pathos with the values of solidarity and openness that the Commission seeks to establish.

\section{Building on legacy, fear and a sense of guilt}

The White Paper depicts EU founders' dream that emerged from the ashes of the Second World War. It mentions it was a vision expressed by a manifesto of two "political prisoners locked up by the fascist regime... during the second World War." Reminding "the images of battles in trenches and fields in Verdun" it contends that "the sacrifice of previous generations should never be forgotten. Human dignity, freedom and democracy were hard-earned and can never be relinquished." 31

This message involves a reference to shared history ${ }^{32}$ as well as the use of a shared heroic myth. ${ }^{33}$ It succeeds to simultaneously trigger pride ${ }^{34}$ (for the war victory and

29 On the importance of rhetoric in the modern approach towards history see GINZBURG, Carlo. History, Rhetoric and Proof. Hanover and London: University Press of New England, 1999.

30 GROSS, Daniel. The Secret History of Emotion: From Aristotle's Rhetoric' to Modern Brain Science. London: the University of Chicago Press, 2006, p. XXVI.

31 JUNCKER, op. cit., n. 4, p. 6.

32 In old Athens, the citizen masses of Athens, elite Athenian politicians and litigants needed to address large bodies of ordinary citizens acting as jurymen and assemblymen in terms understandable and acceptable to them. Among other rhetoric tactics, they referred to history: OBER, Josiah. Mass and Elite in Democratic Athens: Rhetoric, Ideology, and the Power of the People. Princeton: Princeton University Press, 1989, pp. 177-181.

33 The use of a beroic myth characterized, for example, the rhetoric of Winston Churchill. See analysis of his rhetoric and rhetoric tactics of other global leaders in CHARTERIS-BLACK, op. cit., n. 7.

34 On the importance of invoking citizens' pride to obtain political achievements see the example of China: GRIES, Peter. China's New Nationalism: Pride, Politics, and Diplomacy. Berkeley, Los Angeles, London: University of California Press, 2004. 
the establishment of the EU - a following achievement), fear (from potential future wars if the EU does not stick together) and a sense of guilt (we should not be held responsible for destroying the project for which so many lost their lives).

Scaring tactics are very well-known and effective rhetoric devices. ${ }^{35}$ The sense of fear is reinforced by the repetition of the word 'security' 28 times in the text, while words with more positive and constructive connotation appear considerably less times in the text: e.g. 'achieve(ment)' - only 8 times, and 'prosperous/prosperity' - only 2 times.

The emotion of fear is further reinforced by enumeratio ${ }^{36}$ - a rhetoric technique using many details to make a point. The White Paper elaborates on the current and future EU difficulties using statistics, diagrams, graphs etc. to make its point. ${ }^{37}$ These details indicate the risk of losing the EU's competitive position in the world, which in combination with the emphasis on an increased militarization around the world inspires fear.

Pride is strongly associated with a sense of belonging ${ }^{38}$ which the Commission wants to encourage among EU citizens, towards the EU. It may invoke a willingness to be part of a group considered to be successful. Particularly in situations of insecurity one may seek protection. Establishing fear in combination with positioning itself as a strong institution that praises its achievements (as discussed above), the Commission uses pride to give its member states a sense of security.

To that extent, the Commission uses the rhetoric technique of simile ${ }^{39}$ - compares one object to another, in this case current EU citizens to their ancestors: "Like generations before us, our response to the task ahead cannot be nostalgic or short-term."40; "Like the generations before us, we have Europe's future in our own hands." ${ }^{41}$ Failure to obtain these achievements would imply guilt.

In line with this sense of responsibility the Commission takes its responsibility to admit its failures. More than the Five Presidents Report, the White Paper seems to admit current failures and challenges instead of ignoring them, pretending 'business as usual'. Probably, the Commission assumed that such a sincere approach may be appreciated

35 E.g. WALTON, Douglas. Scare Tactics: Arguments that Appeal to Fear and Threat. Kluwer Academic Publishing, 2000.

36 YOURDICTIONARY, op. cit., n. 11.

37 JUNCKER, op. cit., n. 4, pp. 8-11.

38 VAN HILVOORDE, Ivo, Agnes ELLING and Ruud STOKVIS. How to influence national pride? The Olympic medal index as a unifying narrative. International Review for the Sociology of Sport [online]. 2010, Vol. 45, no. 1, pp. 87-102. Available at: http://journals.sagepub.com/doi/pdf/10.1177/1012690209356989

39 YOURDICTIONARY, op. cit., n. 11.

40 JUNCKER, op. cit., n. 4, p. 7.

41 Ibid., p. 26. See example for political rhetoric using a vision of the future to demonstrate a current threat in the US in DUNMIRE, Patricia. Preempting the future: rhetoric and ideology of the future in political discourse. Discourse \& Society, 2005, Vol. 16, no. 4, pp. 481-513. 
by the readers, improving its reliability. However, this approach may not necessarily work. The relationship between rhetoric and truth is a highly conflicted topic. Plato, for example, argued that rhetoric is merely a useful craft that deals only in the subjective and material world rather than in the pursuit of true knowledge. Nietzsche, on the other hand, argued that the debate between rhetoric and truth is meaningless, since individuals are incapable of being completely objective, thus necessarily depicting a subjective picture. Relying on Aristotle, yet a third approach stresses the difficulty to distinguish 'true' from 'false' in any argument, including political and legal ones. ${ }^{42}$ Since all these philosophers seem to grasp that the perception of 'truth' is subjective, one may assume that the Commission picked only the 'true' facts that serve its message best, or presented them in a manner serving its message.

However, the Commission's rhetoric on the sense of responsibility changes tone when it comes to the role of its member states and citizens, aimed at justifying itself against criticism while invoking the latter's sense of guilt.

Under the title "a questioning of trust and legitimacy" lity for the current EU crises from EU institutions to the global atmosphere of insecurity. According to the White Paper, this atmosphere often leads to "indifference and mistrust" and "also creates a vacuum too easily filled by populist and nationalist rhetoric." 44 Here, the Commission seems to express its frustration of right-wing nationalist movements that gain strength all over Europe, urging that blaming 'Brussels' is counter-productive. This message complements the former message about the risks of nationalism and 'isolationism' 45 in an uncertain world.

In the spirit of admitting failures, to project 'frankness', the Commission admits that support of the European project has decreased and that even where it exists, it is no more unconditional. The Commission admits that the gap between promise and delivery should be closed to regain the public's trust, but argues that sometimes the public is not aware of EU's contribution to positive aspects of their daily lives. ${ }^{46}$ The Commission partly directs responsibility to its Member States for not promoting and communicating the efforts Brussels undertakes and participating in "the habit of finger-pointing", ${ }^{47}$ instead of distancing itself from it.

At the core of the value of solidarity is the image of the Commission as an institution 'with teeth'. This is also hidden in small details such as the number of 27 Member States,

\footnotetext{
42 TAMEN, Miguel. Not Rhetoric, Truth. Law and Literature, 2009, Vol. 21, no. 1, pp. 93-105.

43 JUNCKER, op. cit., n. 4, p. 12.

44 JUNCKER, op. cit., n. 4, p. 12.

45 Ibid., pp. 9, 26.

46 Ibid., p. 12.

47 Ibid.
} 
or EU27. ${ }^{48}$ The number is clearly not counting the UK as future Member State of the EU. This exclusion can appear logical after the controversial referendum that took place in the UK two years ago. However, taking into account that the White Paper dates from the $1^{\text {st }}$ of March 2017 and is written before UK's formal request to exit, and considering that other options are available, e.g. leaving out any number of Member States, one can conclude that it does not testify of a cautious and attentive stance towards the controversial debates that took place within the UK. An interpretation of the Commission's stance as a strong message to any member state not willing to support the EU project is therefore not surprising.

As a consequence of the use of pathos, the emotion of fear is likely to cause a sense of urgency to act. The emotions of pride and guilt may prevent the audience from critically considering the Commission's insistence on the necessity to "speak with one voice", "to take care of our own power" and no longer be a "soft power". ${ }^{49}$

\section{Logos: Appeal to Reason}

According to Aristotle, logos - the third artistic proof of rhetoric - is the 'appeal to arguments based in reason'. It uses reason to come to certain conclusions. A frequently employed tool is syllogism: deducting a conclusion from the combination of a general statement (the major premise) and a specific statement (the minor premise). In rhetoric, speakers often leave out a premise. These incomplete syllogisms are also known as enthymemes. Enthymemes are less transparent, as one of the premises is assumed and not made explicit. Often the premise that is generally known or controversial is omitted. The enthymeme may also have become part of a certain belief-system on which institutions are based. According to Feldman et al..$^{50}$, finding oppositions in the narrative helps revealing the enthymemes.

The Commission's argumentation in the White Paper results in concluding that the way forward is 'together'. As shall be discussed below, it uses two ways to arrive at this conclusion. Similarly to the Five Presidents Report it describes a future for the European Union based on shared values, it outlines shared threats, and uses both the values and the threats to conclude in favor of deeper integration. The last part of this section shall interpret the differences between the two documents by means of a close reading focusing on enthymemes hidden in the text.

48 JUNCKER, op. cit., n. 4, title page and pp. 15-26.

49 Ibid., pp. 8-9.

50 FELDMAN, Martha, Kaj SKOLDBERG, Ruth BROWN and Debra HORNER. Making Sense of Stories: A Rhetorical Approach to Narrative Analysis. Journal of Public Administration Research and Theory, 2004, Vol. 14, no. 2, pp. 152. 


\section{Shared values}

Like the Five Presidents Report, the White Paper urges EU members and citizens to overcome current controversies by taking united action to confront the challenges ahead.

Both assume that the EU still relies on a solid ground of values shared by all its members and citizens. The Five Presidents Report addresses values associated mainly with economic and financial context such as "create a better and fairer life for all citizens", "prepare the Union for future global challenges" (based on the assumption of future integration) and "enable each of its members to prosper." 51

The White Paper presents a broader list of mutually shared values, including the desire for peace and prosperity, freedom, tolerance, diversity of culture, ideas and traditions, equality, solidarity, democracy, freedom of expression, rule of law, ${ }^{52}$ security and global contribution (environment, sustainable development, aid), ${ }^{53}$ free movement within the $\mathrm{EU}^{54}$ and better future for the children. It reiterates: "these values and aspirations will continue to bind Europeans and are worth fighting for." ${ }^{55}$

\section{Internal challenges and external threats ahead}

Both documents elaborate on the potential threats ahead, using them as leverage to encourage a decision in favor of further integration. Due to its subject matter, the Five Presidents Report focuses on the financial and economic threats, ${ }^{56}$ while the White Paper draws a more general picture, depicting internal challenges and external threats:

\section{Internal challenges}

- The democratic deficit: the Five Presidents Report addresses this challenge only implicitly, calling for more involvement of the European Parliament and the national parliaments in decision making processes. ${ }^{57}$ The White Paper explicitly admits that "many Europeans consider the Union as either too distant or too interfering in their day-to-day lives." 58

- Unlike the Five Presidents Report, the White Paper explicitly admits Citizens' disappointment: "the EU fell short of their expectations as it struggled with its worse financial, economic and social crisis in post-war history." 59 This different approach

\footnotetext{
51 JUNCKER, op. cit., n. 1, p. 2.

52 JUNCKER, op. cit., n. 4, pp. 6, 26.

53 Ibid., p. 8.

54 Ibid., p. 11.

55 Ibid., p. 26.

56 JUNCKER, op. cit., n. 1, pp. 4, 17.

57 Ibid., pp. 17-18.

58 JUNCKER, op. cit., n. 4, p. 6.

59 Ibid.
} 
may mark an attempt to signal the readers that 'Brussels' is listening to them and knows how they feel.

- Both documents admit that economic recovery from the global financial crisis is "still not felt evenly enough." ${ }^{0} 0$ The Five Presidents Report uses this fact as leverage to argue that full recovery depends on full economic, fiscal and financial unions ${ }^{61}$ while the White Paper allegedly seems to deliver a more moderate message.

- The demographic threat: the White Paper mentions the shrinking population compared to the rest of the world, and the growing bulk of aging population. ${ }^{62}$

- Economic and financial difficulties imply that "for the first time since Second World War, there is a real risk that the generation of today's young adults ends up less well-off than their parents." This gap may imply brain drain which Europe cannot afford. ${ }^{63}$

\section{External threats}

After specifying the internal threats, the Paper moves on to describe the external threats the EU currently faces:

- Political threats, including: neighborhood's instability leading to the refugees' crisis, terrorist attacks in EU cities, emergence of new global powers and the Brexit. ${ }^{64}$

- Security threats, including large-scale cyber-attacks and more traditional forms of aggression. The White Paper stresses the limits of NATO's potential intervention power. ${ }^{65}$

- Economic threats: Europe's share in global GDP is shrinking, other coins are gaining global weight, threatening the superior position of the Euro. ${ }^{66}$

In line with the previous section on pathos, these elements inspire fear, leading to the following logical conclusion 'together we are strong': "in an uncertain world, the allure of isolation may be tempting to some, but the consequences of division and fragmentation would be far-reaching." ${ }^{\prime 67}$ Comparing a desired option with the worst-case scenario - a rhetoric device known as 'relative privation' ${ }^{68}$ - the Paper advocates further integration as better than fragmentation.

\footnotetext{
60 JUNCKER, op. cit., n. 4, p. 9.

61 JUNCKER, op. cit., n. 1, p. 4.

62 JUNCKER, op. cit., n. 4, pp. 8, 10.

63 Ibid., p. 9.

64 Ibid., p. 9.

65 Ibid., p. 8.

66 Ibid.

67 Ibid., p. 26.

68 BENNETT, Bo. Relative Privation. Logically Fallacious: The Ultimate Collection of Over 300 Logical Fallacies [online]. 2012. Available at: https://www.logicallyfallacious.com/tools/lp/Bo/LogicalFallacies/155/ Relative_Privation
} 


\section{Enhanced integration is the answer}

The Five Presidents Report reiterates: "the notion of convergence is at the heart of our Economic Union: convergence between Member States towards the highest levels of prosperity; and convergence within European societies, to nurture our unique European model." 69

The White Paper leads to this conclusion less boldly. Nevertheless, the Commission does not hide its support of the fifth scenario this paper suggests.

Jean Claude Juncker writes in his forward to the White Paper: "Europe has always been at its best when we are united." ${ }^{, 70}$, mentioning that the Lisbon Treaty "still holds unfulfilled potential". ${ }^{71}$

The White Paper specifies the detailed justification behind this proposition:

- Security-wise, in light of international threats mentioned, 'being a 'soft power' is no longer powerful enough." ${ }^{72}$ In the internal context, the future of open borders is at risk in light of migration challenges that are expected to grow. ${ }^{73}$

- Trade-wise, "the return to isolationism has cast doubts over the future of international trade and multilateralism." 74

- Socially-wise, referring to the risk of unemployed youngsters' brain drain, it determines: "Europe cannot afford to lose the most educated age group it has ever had". 75 The aging population challenge, enhanced employment, the strive towards gender equality at work and the need to define new social rights, reflecting the changing reality at work are mentioned as another social challenge that the EU can handle better than each member state. ${ }^{76}$ The problem of Muslims' non-assimilation is addressed only indirectly, contending that "the attachment to peace is not one that all of today's Europeans can relate to in the same way as their parents and grandparents" and that the EU offers "diversity of culture, ideas and traditions." 77

- Environmental challenges are mentioned as another issue where action at EU level offers value added over national action. ${ }^{78}$

\footnotetext{
69 JUNCKER, op. cit., n. 1, p. 7.

70 JUNCKER, op. cit., n. 4, p. 3.

71 Ibid., p. 7.

72 Ibid., p. 9.

73 Ibid., p. 11.

74 Ibid., p. 9.

75 Ibid.

76 Ibid., p. 10.

77 Ibid., p. 6.

78 Ibid.
} 


\section{Multilateralism vs, isolationism}

Overall, the White Paper seems more comprehensive than the Five Presidents Report. It includes more dimensions and takes aboard citizens' increasing lack of trust in the European institutions. Whereas the arguments in the Five Presidents Report are more compelling, the arguments in the White Paper are more considerate of day-to-day reality. However, at the core of its reasoning a less flexible belief-system can be detected that reveals certain limits of the Commission's openness.

On the basis of a close reading in line with the method of Feldman et al. ${ }^{79}$ many opposite narratives can be detected in the White Paper: the story of a past generation vs the story of the current generation; the story of the use of force vs the rule of law; the current threats inspiring fear vs the capacity to overcome difficulties inspiring hope. Detecting the main story line in the many elements, facts, concepts raised, is searching for recurrent patterns in argumentation. The less explicit opposition that is persistently present (either explicitly or implicitly) and that touches upon the democracy deficit is the opposition between multilateralism and isolationism. Throughout the White Paper different passages express a belief-system based on the assumption that multilateralism is merely a positive development, such as "the shared conviction that by coming together, each of us will be better off", 80 and the story of success connected to the EU being the largest single market and being attractive to many partners. ${ }^{81}$ Multilateralism is considered a fundamental condition to continue "Europe's role as a positive global force" $" 82$ and its promotion of a policy of globalization that "benefits all."

In contrast, isolationism is (as the term itself already indicates) characterized as an understandable yet dangerous and risky development. Isolationism equals separation (Brexit), it equals division and fragmentation, it equals disunity. It would "expose European countries and citizens to the spectre of their divided past and make them prey to the interests of stronger powers". ${ }^{84}$

The opposition between multilateralism and isolationism is again reflected in the binary choice between two alternatives as presented by Juncker in his State of the Union Address "we only had two choices. Either come together around a positive European agenda or each retreat into our own corner." 85 Based on the assumptions as explained above the choice is easy: coming together ensures progress, isolation is a step backwards and risky.

79 FELDMAN, SKOLDBERG, BROWN, HORNER, op. cit., n. 50, pp. 147-170.

80 JUNCKER, op. cit., n. 4, p. 7.

81 Ibid., p. 8.

82 Ibid.

83 Ibid., p. 9.

84 Ibid., p. 26.

85 JUNCKER, Jean Claude. State of the Union Address [online]. 2017. Available at: https://ec.europa.eu/ commission/state-union-2017_en; http://europa.eu/rapid/press-release_SPEECH-17-3165_en.htm 
This opposition reveals that although the White Paper may appear more considerate of the internal challenges related to the democratic deficit and the citizens' increasing lack of trust, its fundamental belief in liberalization and open market is still unaltered and unquestioned. Consequently, it risks to overlook criticism underlying the increasing call for 'isolationism', and populist and nationalist voices, criticism that touches upon the utopia of multilateralism itself, but that, in a deliberative democracy, may help to find a more balanced approach towards liberalization. Instead, the Commission uses the internal and external threats to urge the member states to speak with one voice.

The combination between the sense of urgency and the image of a strong institution with teeth can easily lead to convincing the stakeholders in the decision-making process to speed up the decisions on the future of Europe without taking the necessary time and attention for deliberations between the variety of voices present in the EU today.

\section{Section 3: The Five Scenarios}

Scholars suggest that in organizations, "a specific combination of messages - a large amount of vision imagery combined with a small number of values - will boost performance more than other combinations because it triggers a shared sense of the organization's ultimate goal, and, in turn, enhances coordination." 86 They stress the importance of this delicate formula, warning that communicating visions without imagery or overutilization of value-laden rhetoric would not gain the same effect. ${ }^{87}$ Unlike the Five Presidents Report, focused on one scenario: the creation of full economic, financial and fiscal unions, expressing a desire for a political union to follow, the White Paper's rhetoric seems to draw on this technique. It suggests a reference to a small number of values repeated through the text with five sketched scenarios for the future imageries (explicitly using the word 'snapshots' to describe pictures giving an idea about each scenario's possible consequences), leaving a great room for their readers' imagination, to trigger their enthusiasm to participate in creating a shared sense of a mutual vision forward.

Each one of these scenarios implies another level of integration.

The second part of the White Paper, specifying these scenarios, opens up by specifying the assumptions underlying them: ${ }^{88}$

- The transformations Europe is undergoing will persist.

- Other, unpredictable transformations, may follow.

86 CARTON, Andrew, Chad MURPHY and Jonathan CLARK. A (Blurry) Vision of the Future: How Leader Rhetoric about Ultimate Goals Influences Performance. Academy of Management Journal, 2014, Vol. 57, no. 6, pp. 1544-1570.

87 Ibid.

88 JUNCKER, op. cit., n. 4, p. 15. 
- Europe can either be carried away by these events or seek to shape them, i.e. chose an active or a passive role.

- In any scenario chosen, the 27 member states stay together.

In the spirit of the philosophical doubts (presented above) regarding the essence of truth, each of these assumptions may be doubted or replaced by another assumption, of course. However, they mark the state of mind of their writers and thus, in terms of rhetoric, lay the foundations for the scenarios to come.

The White Paper goes on to explain that the purpose of the five scenarios concept it introduces is to illustrate that the "binary choice between more or less Europe" is "misleading and simplistic". In essence, though, the scenarios only illustrate different variations or combinations of these two extreme possibilities. Moreover, the White Paper admits: "there are many overlaps between each scenario and they are therefore neither mutually exclusive, nor exhaustive." 89

It further assumes that "the final outcome will undoubtedly look different to the way the scenarios are presented here" 90 - namely: signifies that everything is open and that the final choice will be made by the EU 27. However, according to the wording of the White Paper, the choice they will make is "which combination of the features from the five scenarios" they believe will best help advance the European project. If this reading is correct, the White Paper puts forward a modular set of choices, but the choice is limited to the elements included in this set. This implication is literal, but if correct, it collides with the message of full flexibility argued in the first part of this paper. Furthermore, it is rhetorically misleading, because the Commission has no legal power to limit the EU27 choice about the way forward. Maybe this choice of wording aims at directing the public into a limited set of options, to make it easier for them to imagine their consequences and choose the one which is closest to their aspirations. However, at the same time this rhetoric is dangerous because it limits their imagination by implicitly ruling out other possibilities that may be more suitable or successful in dealing with the situation.

Each of the five scenarios is described in one page. All descriptions follow the same rhetoric pattern, to assist readers' orientation and make comparison between them easier: a headline shortly describing the idea behind each scenario; an explanation titled "why and how?"; a part titled "by 2025, this means:"; and finally, in short, the pros and cons of each scenario (followed by a summing up table row and illustrative 'snapshots'). The use of one short template to describe all scenarios, which is some kind of parallelism, makes it easy for the readers to follow them and compare them, to assess their differences. In a way, scenarios description (including its graphic aspect) resembles the concept of designing a PowerPoint presentation, where a design template rhetoric directs

89 JUNCKER, op. cit., n. 4, p. 15.

90 Ibid. 
writers to "use consistently formatted titles; put content in the same places; and limit content for each slide." $" 91$

\section{Scenario 1: continuing the current path of integration}

Scenario $1^{92}$ is titled "carrying on" and its sub-title is "the European Union is delivering its positive reform agenda." The use of the word 'positive' reveals Commission's approach towards this controversial reform, which it initiated and masters. This scenario describes a EU that "sticks to its course", but at the same time "implementing and upgrading its current reform agenda". If this scenario is what the Commission sees as 'status quo" this description is thus inaccurate, since upgrades would eventually boil down to further integration.

The Commission realizes that the joint agenda would have to be determined by the EU 27 and European institutions and that decision-making speed would depend on overcoming differences in views among EU members, to decide long term priorities. Judging upon the current reality, this may be a substantial obstacle towards obtaining any upgrade, a fact mentioned only at the end of the description, as a possible disadvantage. If this scenario works, by 2025 the EU 27 would attempt to strengthen the market economically, to obtain more jobs and growth, and to attract investments by stepping up investments in infrastructure (digital, transport and energy). Financial strength would improve by substantial improvement of the single currency (probably by continuing the implementation of the Five Presidents Report vision, but it is not explicitly mentioned). $90 \%$ of all state aid measures will be in the hands of national, regional and local authorities.

National authorities would share intelligence and deepen defense cooperation and even pool some military capabilities, enhancing financial solidarity for missions abroad. These steps imply advancement towards a military union without saying so explicitly. The White Paper expresses a Commission's anticipation that terrorist and other defense threats would encourage such steps, avoided hitherto. Reinforced cooperation on borders management (with active assistance of the European Border and Coast Guard) complements this picture, although it will stay fully under national responsibility.

In terms of external relations, the EU27 would speak in one voice, continue to conclude trade agreements and manage to positively affect the global agenda on climate, financial stability and sustainable development.

\footnotetext{
91 SULLIVAN, Patricia. The Power of Templates Rhetoric \& Powerpoint [online]. 2016. Available at: http://slideplayer.com/slide/8652100/

92 JUNCKER, op. cit., n. 4, p. 16.

93 Ibid., p. 15.
} 
This scenario depicts a picture of some mild reality, where concrete results are obtained and EU citizens' rights are upheld. However, it does not suggest how to confront the real challenges that prevent current obtainment of this scenario: the huge gaps among member states' interests and motivations, the huge economic and financial gaps between them that were broadened by recent crises, the controversies over the way out of each of the crises etc. Additionally, it overlooks many elements involved in EU's daily life and struggles, not describing how they will fit in this generally depicted picture.

\section{Scenario 2: reverting to the single market only}

The second scenario ${ }^{94}$ is titled 'Nothing but the single market'. If the former scenario is perceived as 'status quo', this one may fit into the description of "changing of scope and priorities". ${ }^{95}$ In essence, though, it implies withdrawal from the EU's current course into gradual re-centering on the single market only, due to the EU27 inability to reach agreement on many issues. This scenario implies abandoning common action in many fields, of which the Commission deliberately chose to mention migration, security and defense, three issues now under deep controversies. However, at the same time the Commission avoids mentioning many other, maybe less controversial issues, which will return to national or bilateral management in this process. This rhetoric expresses Commission's frustration of the current situation (clearly expressed by an explicit relief of the anticipated decreasing legislation burden).

Issues that will gradually return to national regulation due to this process would include consumer, social and environmental standards, taxation (including fighting tax evasion), the use of public subsidies, migration, foreign policy.

Mobility of workers and the stability of the single currency would suffer, as well as the free movement of persons, due to intensified border checks.

In the global arena, the EU would find it more difficult to agree the terms of trade agreements and would have less effect on issues such as climate change harnessing globalization, since it will not speak in one voice.

This scenario seems to have some rhetoric purposes: first, to signify to the readers the alleged indifference of the Commission to their choice, allegedly implying its objectivity. Second, to illuminate the former scenario as not the worst-case scenario: the Commission definitely prefers a slow prospect of integration enhancement over withdrawal from this process. In this spirit, it mentions to the readers all the benefits they may lose if they choose this path. (Using rhetoric device of 'relative privation'). ${ }^{96}$

\footnotetext{
94 JUNCKER, op. cit., n. 4, p. 18.

95 Ibid., p. 15.

96 BENNETT, op. cit., n. 68.
} 
In this context, one of the advantages the Commission mentions for this scenario: "decision making may be simpler to understand", may be interpreted as bitter irony.

\section{Scenario 3: intensifying the use of 'enhanced cooperation' mechanism}

The third scenario is titled "those who want more do more". It focuses on enhanced cooperation, which already exists in the EU, legally and pragmatically. It describes a process where the majority of member states continues in the path described in scenario 1, while other member states deepen cooperation in chosen domains. As examples for such domains it mentions defense, internal security, taxation and social matters, thus indicating that the Commission does not expect obtainment of integration at EU level regarding these issues in the near future.

In terms of rhetoric, this scenario may serve some purposes: first, it gives the Commission an opportunity to encourage frustrated partners who wish to move forward in higher speed. Second, it serves to send an implied threat to those members holding back the integration process, that others may not wait for them forever, hence inspiring a certain sense of guilt when not choosing for further integration. Although legally they have the right to join such processes at any stage (and the Commission stresses it in the scenario described), it is obvious that while they hesitate others might gain a competitive advantage by joining the process from the start and shaping it to serve their interests best. Member states choosing for the slower pace may thus experience a sense of anxiety over losing position on the European market that may undermine the sense of solidarity. Moreover, although in the short run "the unity of the EU at 27 is preserved", ${ }^{97}$ if these practices prosper, the foundations of the EU would gradually destabilize as variance would prevail over convergence. This is shortly addressed in the 'pros and cons' section. This is 'window of opportunity' rhetoric device, meant to trigger a sense of urgency and a risk to lose if the opportunity is not materialized on time. This scenario also seems to aim at illuminating other scenarios in a better, more desirable, light ('relative privation').

\section{Scenario 4: selective integration}

The fourth scenario is titled "doing less more efficiently". It may also fit into the description of "changing of scope and priorities". ${ }^{98}$ It suggests that the EU would focus on certain priority areas, delivering more and faster in them, at the cost of returning other policy areas to national responsibility, or doing less at EU level. The Commission stresses that such a choice would serve as an opportunity for the EU27 "to better align promises, expectations and delivery", 99 to prevent scandals emanating from expectation that the

\footnotetext{
97 JUNCKER, op. cit., n. 4, p. 16.

98 Ibid., p. 15.

99 Ibid., p. 22.
} 
EU takes care of or issues it does not have power or tools to handle. Mentioning the emission scandal as example, this is another expression of the Commission's frustration. This scenario also implies some revert from the current stage of integration, in terms of scope of issues handled by the EU.

The issues on which the Commission suggests to focus the EU efforts include innovation ( $\mathrm{R} \& \mathrm{D}, \mathrm{EU}$-wide projects to support decarbonization and digitation, deepen cooperation on hi-tec and space projects, completion of regional energy hubs), trade, security, migration, the management of borders and defense. In the former scenario, the Commission suggested to abandon EU treatment of the four latter issues. Consequently, this suggestion may be interpreted as an alternative, but it seems more likely that the former suggestion was only a rhetoric exercise, also building on the 'relative privation' technique, while this one reveals the true priorities according to the Commission.

It urges the development of "stronger tools... to directly implement and enforce collective decisions, as it does today in competition and banking supervision". ${ }^{100}$ In addition, this scenario suggests taking further steps to consolidate the Euro area. Thus, if chosen, the Commission may perceive it as a feasible interim stage, serving the longterm vision of enhanced integration. Although rhetorically, the paper abstains from presenting it as such, other anticipated developments reinforce this assumption: cooperation between police and judicial authorities, mentioned in the context of counterterrorism acts, may yield further cooperation between these authorities in the future; "The European Border and Coast Guard fully takes over the management of external borders" 101 and a single asylum agency processes all asylum claims. Joint defense capacities are established.

While these integrative steps take place, this scenario foresees the abandonment of EU responsibility in other fields, such as: regional development, public health, parts of employment and social policy not directly related to the functioning of the single market, state aid control. It suggests to determine only minimum standards at EU level regarding consumer protection, the environment, health and safety at work. The Commission justifies the choice of these fields as domains where the EU "is perceived as having more limited added value, or as being unable to deliver". ${ }^{102}$ This may be interpreted as either admitting failure and attempting to withdraw such fields associated with failure in order to improve EU's image as a delivering, reliable and responsible entity, or as an attempt to diminish the chance for failure (and improve EU's image) in the short and medium term, planning to resume authority on these issues at a later, better timing (if such a plan exists, it is obviously not admitted in this paper). Yet, another

\footnotetext{
100 JUNCKER, op. cit., n. 4, p. 22.

101 Ibid.

102 Ibid.
} 
interpretation may suggest that the potential fields recommended for abandonment: the environment, consumer protection, health and safety at work, are decisive to the functioning of the single market and at the same time bear personal implications for most EU citizens (particularly the first two), so maybe the Commission makes a political gamble that the imagery this scenario depicts may invoke EU citizens' fear to lose the benefits emanating from EU treatment of these issues, thus rejecting this scenario. The closing sentence of this scenario, reiterating that "to start with, the EU 27 has real difficulty in agreeing which areas it should prioritise or where it should do less" 103 supports this assumption.

In the pros and cons section, the Commission stresses the "clearer division of responsibilities" that "helps close the gap between promise and delivery, even if expectations remain unmet in certain domains" as an alleged major advantage. In the context, this position seems a self-righteous rhetoric.

\section{Scenario 5: enhanced comprehensive integration}

All proposed scenarios seem to lead to Scenario 5, titled "doing much more together". The choice to present it as the last option seems to signalize that this is the scenario the EU Commission prefers and aims at, based on the build-up rhetoric it used hitherto.

It foresees enhancement of cooperation between all member states, in all domains, including the Euro. Consequently, decision making is more rapid and enforcement improves. Since the EU speaks with one voice it gains more international effect in matters such as climate change, development and humanitarian issues. A European defense union is created. Europe develops a joint approach on migration and increases investments in its neighborhood and beyond. Internally, it strives towards completing the single market, creating a European 'Silicon Valley', fully integrated capital markets and greater coordination on fiscal, social and taxation matters. As pros, the White Paper mentions far greater and quicker decision making at EU level and more citizens' rights driven directly from EU law. As cons, it refers to the risk that for part of the society, the 'democratic deficit' feeling may strengthen.

Nevertheless, even here, the Commission avoids depicting a picture of full economic, financial and fiscal unions, followed by a political union, as it did in the Five Presidents Report.

\section{Conclusion}

The White Paper follows the same narrative that characterizes many EU Commission's documents, including the Five Presidents Report.

103 JUNCKER, op. cit., n. 4. 
This narrative includes the following milestones:

- The EU is a global, leading super-power. It is a global success and a project to be proud of, obtained by sacrifice of many that should not be wasted.

- During its 60 years of existence the EU has overcome many obstacles and challenges.

- Despite controversies, its strength lies in the shared values and interests of its members.

- The EU is now facing severe challenges.

- If not properly treated, these challenges may threaten the security/welfare of EU member states and citizens.

- If properly treated, these obstacles may be used as leverage to improve, strengthen and enhance the EU project, to the benefit of its member states and citizens.

- The best way forward is to enhance integration in all fields.

A French saying contends that 'the tone makes the music'. Indeed, due to the growing criticism invoked in recent years, the EU Commission has slightly changed the tone of this message, by admitting its failure to meet EU citizen's expectations in recent years and by allegedly suggesting that the public pick the desired scenario forward.

However, despite the different tone, it is clear that the EU Commission has not changed the music, or the essence of its message: it still believes that the best way forward is by enhancing EU integration, in as quick and comprehensive a manner as possible. Needless to say, this way serves the EU Commission and its interests best.

The Commission uses various rhetoric techniques and devices to pass this message despite the alleged change of tone: it creates an illusion of a platform for an open public discourse leading for a choice of a way forward, supported by straightforward language and illustrative graphics. It appeals to the shared history and legacy, to the shared values and the sense of common responsibility for future generations, presenting a detailed description of the threats ahead, to 'build up' towards the option desired by the Commission. These messages are conveyed through the Aristotelian artistic proofs of ethos, pathos and logos and appear to be less inclusive than pretended: they are based on an implicit belief-system that multilateralism is the unquestionable way forward and isolationism - a development to be condemned.

Calling for an open public discourse and specifying the platform for it, the Commission suggested initiating a series of reflection papers on the issues at stake. While it promised that these papers, like the White Paper, will suggest different ideas to open a debate, their titles already implied the state of mind underlying them: "developing the social dimension of Europe; developing the Economic and Monetary Union on the basis of the Five Presidents Report; harnessing globalization; the future of Europe's defence; the 
future of EU finances." "This list made it clear that the Commission has not given up on many of the issues it allegedly suggested to transfer back to national treatment, and that it does not really believe that any of the scenarios suggesting so would be chosen by EU citizens and decision makers.

On September 13 2017, six months after the initiation of the White Paper, the President of the European Commission, Jean Claude Juncker, in the State of the Union Address, pulled the rabbit out of his hat, presenting his view or 'scenario six'. Reiterating that "the future cannot remain a scenario, a sketch, an idea among others" he strongly advocated the need to comprehensively strengthen integration, to include a stronger single market, a stronger economic and monetary union, a European minister of Economy and finance, a European intelligence unit and a European public prosecutor, a European defense union. ${ }^{105}$

Although his message mentioned the public debate triggered by the White Paper, and the 2000 public events the Commission initiated for this purpose, it did not refer at any point to any essential conclusions such debate may have yielded. This reinforces this article's analysis of a rhetoric that serves to change the tone while aiming for the same purpose of furthering European integration. The announcement on the establishment of a subsidiarity and proportionality task force, to make sure the EU would only act where it has value added, and on planned steps to reinforce the democratic nature of the EU may serve as additional rhetoric or political attention distractors from the clear and determinant strife of the Commission to enhance integration despite the broad EU public's resistance.

However, if the White Paper was just a rhetorical exercise, its initiators should take into account that

"The danger (or promise, depending on one's perspective) is that rhetoric encourages a skeptical attitude toward the very institutions it helps compose. Historical rhetoric reminds us that, however real and consequential they might be, the institutions that help shape us are ultimately of our own making and therefore are subject to change."106

The Commission's narrative invoking the emotions of fear, pride and guilt may create an atmosphere of mistrust if it continues to turn a deaf ear to the real concerns that are swept aside as 'isolationism'.

104 JUNCKER, op. cit., n. 4, p. 26.

105 JUNCKER, op. cit., n. 85.

106 GROSS, op. cit., n. 30, p. XXIII. 